\title{
Serge Morand and Muriel Figuié (eds), 2016, Emergence de maladies infectieuses. Risques et enjeux de société (The emergence of infectious diseases. Societal risks and stakes)
}

Paris, Quae, 136 p

\author{
Laure Bonnaud $^{1} \cdot$ Nicolas Fortané $^{1}$
}

AIDS, SARS, avian influenza, swine influenza, West Nile virus, Ebola, Zika... infectious diseases, and pandemic influenza in particular are at the heart of the collective work coordinated by Serge Morand and Muriel Figuié. This book, in French, offers a precious, multidisciplinary introduction to the emergence of diseases affecting public health. Divided into five dense chapters, it sets out the main questions, concepts, and policy instruments relating to the construction of this new global public issue. Given that the majority of emerging diseases are zoonotic (animal transmitted), essentially caused by viruses or bacteria, the book opts for a "One Health" framing": it investigates the relationship between human beings, animals, and the environment, particularly the role that animal reservoirs plays in the appearance and extension of human pathologies. It also immediately adopts an international perspective: whilst issues relating to new emerging diseases tend to be examined in the northern countries, they more often than not appear in intertropical zones (Southern and South-Eastern Asia, Central Africa); this is due on the one hand to the rich biodiversity of these zones (both in terms of micro-organisms and species of animals and plants) and on the other to their social and cultural organisation in terms of healthcare, agriculture, and urbanism. So it is not surprising that emerging infectious diseases have given rise to unprecedented international cooperation and to the development of new tools for managing global health.

\footnotetext{
${ }^{1}$ One World One Health is "a cross-sectoral and interdisciplinary approach that recognises risks at humananimal-ecosystem interfaces" (Chien 2013, p. 214).
}

Laure Bonnaud

laure.bonnaud@inra.fr

Nicolas Fortané

nicolas.fortane@inra.fr

1 RiTME, INRA, 94200 Ivry-sur-Seine, France 
International organisations (World Health Organization (WHO), Office International des Epizooties or World Organization for Animal Health (OIE), Food and Agriculture Organization of the United Nations (FAO)) play a leading role in coordinating the exchange of surveillance information and in facilitating the implementation of tools to fight disease.

Twenty-five years after Stephen Morse's seminal work which helped put emerging infectious diseases onto the political and scientific agenda (Morse 1993), contemporary debates were very much influenced by an article published in Nature in 2008 (Jones et al. 2008). Jones and his colleagues presented three major results: the regular and significant increase in the number of infectious diseases that had emerged since the 1940s, the role played by viruses and bacteria (with parasites playing a secondary role), and finally, the animal origin of this phenomenon. In order to understand what might seem to be an inevitable biological evolution, the book takes a multidisciplinary approach: whilst the origin of these infections is definitely animal, it is human societies, through their lifestyles, which are responsible for their propagation - as S. Morand immediately points out in the first chapter devoted to a presentation of definitions, the state of scientific debate, and the main available epidemiological data. The following three chapters set out to deconstruct the apparent evidence of international mobilisation against these emerging diseases. Claude Gilbert and Nathalie Bender show how the influenza pandemic constituted an interesting opportunity for WHO, an international organisation in crisis since the 1990s. At the beginning of the 2000s, WHO decided to reposition itself as a reference centre for biomedical expertise. Its management of the SARS epidemic, through its network of experts and its alert and response system, enabled it to gradually recover an authority that was both moral and technical. In the case of influenza, national experts-virologists in particular-also became lobbyists for this public issue, linking it to other problems (by presenting it as a model for preparations against bioterrorism) and suggesting solutions, such as mass vaccination. In the French case, the authors analyse the mechanism for countering H1N1 flu and look at different ways of shaping the public problem, depending on whether the pandemic is deemed to be a public health issue, a stake of collective security, or a global problem affecting contemporary societies. These different appropriations nevertheless coexist without really impacting one another. They do not lead to any major redefinition of solutions, and mass vaccination remains the solution that health authorities recommend.

In a chapter devoted to the CBRN risks (chemical, biological, radiological, and nuclear) in the USA, Patrick Zylberman retraces the origin of scenario planning, used by public authorities to prepare against threats. He shows that since the end of the cold war, health issues have been taken on board by national security actors whose tools and concepts have gradually taken over. Among the norms, plans, and procedures that constitute the tools with which to prepare for biological, chemical, radiological, and pandemic threats, scenario planning takes pride of place. It is a case of preparing "in order to dissuade", with the idea of a terrorist enemy being implicit. Scenario planning allows one to set probabilities aside and thus bring public authorities into a worst-case logic. P. Zylberman is sceptical about the fictional aspect they contain, which serves just as much the political and ideological motives of domestic policy as truly helping institutions to prepare against threats. 
Muriel Figuié takes a critical state-of-the-art look at the implementation of international public action in relation to animal health and more particularly at epidemiological surveillance and vaccination. She notes recurring observations by international experts of the difficulties involved in coordinating actors and discusses the literature that attempts to explain these issues. Two types of explanations are generally put forward: on the one hand, those which relate to individual determinants and on the other, those which focus on cultural aspects. In the first group, we find cognitive and psychological factors, along with those relating to individual economic calculation. The second group concerns everything relating to inherited beliefs and know-how which prevent any proper understanding of the solutions suggested by experts from international institutions. M. Figuié confronts these analyses with a reflection on conditions for collective action, talking for example about her works on the informal epidemiological surveillance networks which were developed in Vietnam when avian influenza emerged. She reveals the many ambiguities surrounding the mechanisms proposed by southern countries and the controversies and conflicts between actors who are supposed to work together to protect animal health, now regarded as a global public good. We are thus moving away from the vision of a coherent project that local actors cannot or do not want to support, in favour of putting more nuance into the definition of what constitutes the implementation of global health policy instruments. In Vietnam, poultry culling is a tool aiming at preventing the spread of the flu as well as a mean to modernise agricultural system by fostering the development of agri-food industrial actors. This viewpoint is examined in greater depth in the final chapter by François Roger, who focuses on the north/south inequalities that are embedded in plans to monitor and fight infectious diseases.

All of these chapters form a coherent book which offers a very solid introduction to the examination of public action against emerging infectious diseases. They open the road to new research, be it disciplinary or interdisciplinary, which might throw further light on certain aspects currently left in the shadows; they will also be of use to experts and decision-makers.

The analysis of this new global public health model is therefore a convincing one, even though its circulation and eventual local variants remain unknown. The priority given to international institutions might therefore be bolstered by an analysis of regional evolutions which at the very least would appear to have laid the ground for this new model: the European Union's animal health strategy was thus perfectly adapted to a reclassification of animal diseases - but for internal budgetary reasons rather than to fight emerging diseases! (Ollivier 2013). The book also opens the way for in-depth studies of the roles played by the market and by private actors. It very rapidly sets out the foundations, the pharmaceutical laboratories, and the agri-food industry which are vital stakeholders in the fight against infectious diseases - or in their emergence (such as the development and spreading of antimicrobial-resistant bacteria, for example!). Their role could in itself be a research object. Finally, epidemiological surveillance networks aside, the book pays little attention to the implementation of other devices or policies to fight against emerging infectious diseases. In the northern countries, changes to healthcare systems, the medical and paramedical professions, the NGO relating to public health, and more broadly, migratory policies might also throw light on how certain infectious diseases are managed (AIDS is one well-documented example: Gelly et al. 2014). Similarly, countries in the southern countries use a variety 
of devices to fight infectious diseases - such as triage centres or clinical trials set up as part of the fight against the Ebola virus in Africa (Lakoff et al. 2015) — which clearly demonstrate the social, political, technical, and biological complexity surrounding contemporary emergences. The next step towards understanding emerging diseases might therefore be to compare this new global health model with existing devices, in both the northern and southern countries.

It nevertheless remains that this book, both through the concepts and policy instruments it presents and the perspectives it offers, marks an important step forward in the analysis of emerging infectious diseases.

\section{References}

Chien, Y.-J. (2013). How did international agencies perceive the avian influenza problem? The adoption and manufacture of the "One World, One Health" framework. Sociology of Health \& Illness, 35(2), 213-226.

Gelly M., Girard G., Trachman M. (eds.) (2014). La fin du Sida ?, La vie des idées, online publication: http://www.laviedesidees.fr/La-fin-du-sida.html

Jones, K., Patel, N., Levy, M., Storeygard, A., Balk, D., Gittleman, J., \& Daszak, P. (2008). Global trends in emerging infectious diseases. Nature, 451(7181), 990-993.

Lakoff A., Collier S., Kelty C. (eds.) (2015). Ebola's ecologies, Limn, 5, Online publication: http://imn. it/issue/05/

Morse, S. (1993). Emerging viruses. New York and Oxford: Oxford University Press 352 p.

Ollivier, B. (2013). Quand les vétérinaires et les animaux font l'Europe: l'action publique européenne en santé animale. Une institutionnalisation fragmentée, thèse pour le doctorat de science politique, Paris, Institut d'études politiques. 